\title{
Gina Konstantopoulos*
}

\section{The Disciplines of Geography: Constructing Space in the Ancient World}

\author{
https://doi.org/10.1515/janeh-2017-0012
}

Abstract: This article serves as introduction to a special double issue of the journal, comprised of seven articles that center on the theme of space and place in the ancient world. The essays examine the ways in which borders, frontiers, and the lands beyond them were created, defined, and maintained in the ancient world. They consider such themes within the context of the Old Assyrian period, the Hittite empire, and the Neo-Assyrian empire, as well as within the broader scope of Biblical texts and the Graeco-Roman world. As we only see evidence of a documented, physical, and thus fixed map in the later stages of Mesopotamian history, the ancient world primarily conceived of space through mental maps rather than physical ones. Thus, while the societies of the ancient Near East integrated knowledge gained by actual contact with distant lands into their world view, it was also informed by the literary conceptions of those same spaces. These mental maps were unsurprisingly prone to shifting over time, changing as the social conceptions of the world itself, its border and frontiers, the lands that lay beyond them and how those places might be defined, also changed. These papers question the intersection of concrete and fantastical, or real and imagined, that existed in both the ancient and pre-modern world, where distant locations become elaborately embroidered by fantastical constructions, despite the concrete connections of travel, trade, and even military enterprise.

Keywords: cartography, geography, mesopotamia, empire, mental maps, graeco-roman world

This essay borrows its title from Jorge Luis Borges's "On Exactitude in Science," which remains something of a popular introductory ${ }^{1}$ quotation for

1 In full, "On Exactitude in Science,” reads as follows: “... In that Empire, the Art of Cartography attained such a Perfection that the map of a single Province occupied the entirety of a City, and the map of the Empire, the entirety of a Province. In time, those Unconscionable Maps no longer satisfied, and the Cartographers Guilds struck a Map of the Empire whose size

*Corresponding author: Gina Konstantopoulos, University of Helsinki, Helsinki, Finland, E-mail: gina.konstantopoulos@helsinki.fi 
studies dealing with borders and frontiers. Its popularity is easy to understand: aside from its poetic merit, Borges's one-paragraph story provides an interesting thought experiment on the purpose of maps themselves. Borges describes a map that grows until its matches the very empire it depicts in exact scale: a map that is so accurate as to have become not a depiction of the space, but the space itself. ${ }^{2}$ The conception and creation of space in the ancient world is a more tenuous procedure, and at first we might find other, also oft-quoted, adages of more use, such as Alfred Korzybski's statement that: “A map is not the territory it represents, but, if correct, it has a similar structure to the territory, which accounts for its usefulness" (1994: 58). Even this statement, however, may fray when we reach the edges of the constructed map in the ancient world, where the act of creating a map, a mental imaging of distant space, holds as much significance as the reality of the space itself. To this end, we may move even further away from either map, to Jean Baudrillard's (1994: 1) deconstruction of Borges's fable:

Today abstraction is no longer that of the map, the double, the mirror, or the concept. Simulation is no longer that of a territory, a referential being, or a substance. It is the generation by models of a real without origin or reality: a hyperreal. The territory no longer precedes the map, nor does it survive it. It is nevertheless the map that precedes the territory - precession of simulacra - that engenders the territory, and if one must return to the fable, today it is the territory whose shreds slowly rot across the extent of the map.

In considering these three perspectives on maps and mapmaking, we see a development of the relationship between spaces, particularly distant ones, and the ways by which they can be both imagined and constructed. If Borges is situated on the far end, with a map that corresponds exactly to the space it represents, then Baudrillard creates a very different scenario - here, the act of describing space, or of imagining it, even as an abstraction, engenders the very

was that of the Empire, and which coincided point for point with it. The following Generations, who were not so fond of the Study of Cartography as their Forebears had been, saw that that vast Map was Useless, and not without some Pitilessness was it, that they delivered it up to the Inclemencies of Sun and Winters. In the Deserts of the West, still today, there are Tattered Ruins of that Map, inhabited by Animals and Beggars; in all the Land there is no other Relic of the Disciplines of Geography,” (Borges 1999: 325).

2 Korzybski notes that, while maps are only useful if they hold a similar structure to the territory they represent, the act of representation itself is useful beyond maps, applied principally to language itself; (Korzybski 1994: 58).

The idea finds particular use in theories of religion, implemented most famously by (Smith 1978); the use of mapping in as a rhetorical and analytical model in the field is further discussed by (Gardiner and Engler 2010). 
space itself. ${ }^{3}$ What we think about space, then, would matter more than the reality of the space itself. While this may seem a dubious claim in light of the advanced instruments modern cartography has at its disposal, the civilizations of the ancient Near East and Mediterranean had to contend with a world that was far less familiar at its edges. Lands found at the periphery of the known and explored world were often directly correlated with the fantastic and the wondrous, as well as the monstrous and terrifying. Even when those distant locations could be proved as real and even mundane by trade encounters or military contact, the stories of their more fantastic qualities were neither disproven, diminished, nor replaced by the reality of their actual existence.

The papers in this volume began as part of a workshop held in 2016 at the Institute for the Study of the Ancient World, entitled "Hic Sunt Dracones: Creating, Defining, and Abstracting Place in the Ancient World." 4 The initial phrase found in the workshop's title points to one of the more famous pieces of cartographic propaganda. Though the phrase "Hic Sunt Dracones" or "Here be Dragons," is well-known and often quoted, it is found in only two instances: most famously on the Hunt-Lenox Globe, c. 1510 CE (Figure 1) as well as a world map present in a manuscript of Jean Mansel's La Fleur des Histoires, c. 1460-70 CE, a universal history stretching from the world's creation to the reign of Charles VI (1380-1422 CE). ${ }^{5}$ The Hunt-Lenox Globe, a small, engraved copper globe roughly five inches in diameter, is one of the earliest surviving globes and by far the best known of the two examples.

Currently in the collections of the New York Public Library, the globe is of course inaccurate by modern cartographic standards, but does reference Europe's recent, at that point, discovery of the New World, with South America appearing as a large landmass and North America as a group of islands. Close to the southern edge of Africa, we see the inscription "HC SVNT DRACONES” (Figure 2). Though

3 Perhaps the cleanest definition of abstraction and abstracting, in this instance as well as is intended in the title of this volume, is found in a dated (in the literal sense) summation of John Locke's An Essay Concerning Human Understanding, which details: "the power of Abstracting, which is the separating [of] any idea from the circumstances of real existence, as from time, place, and other concomitant Ideas" (Gilbert 1728: 375).

4 The workshop was held on October 28th, 2016. The papers in this volume comprise all of the papers presented at the workshop, and follow the same general thematic arrangement as at the workshop. However, the workshop itself also benefited from lively discussion and debate, with key observations from both Lorenzo d'Alfonso and Sarah Graff, who chaired the morning and afternoon sessions of the workshop.

5 For an overview of the position of the phrase on both maps, (see Van Duzer 2012: 389). The relevant phrase on Jean Mansel's La Fleur des Histoires is discussed in (Scafi 2006: 202-03), the legend on this map reads "hic sunt dragones." 


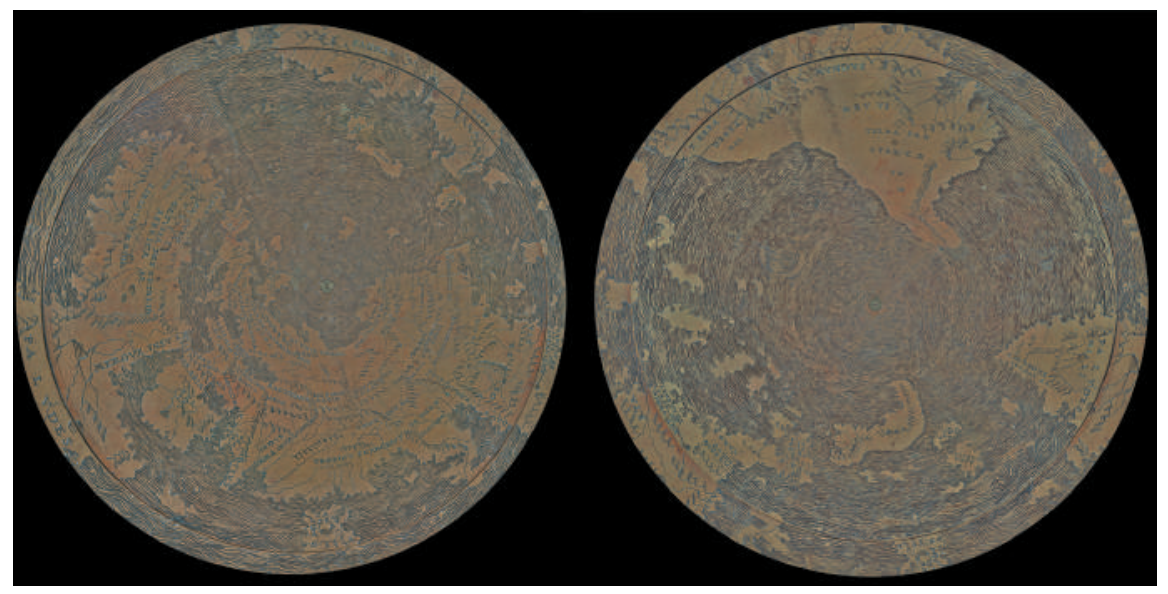

Figure 1: Hunt-Lenox Globe, Northern and Southern Hemispheres New York Public Library, Public Domain.

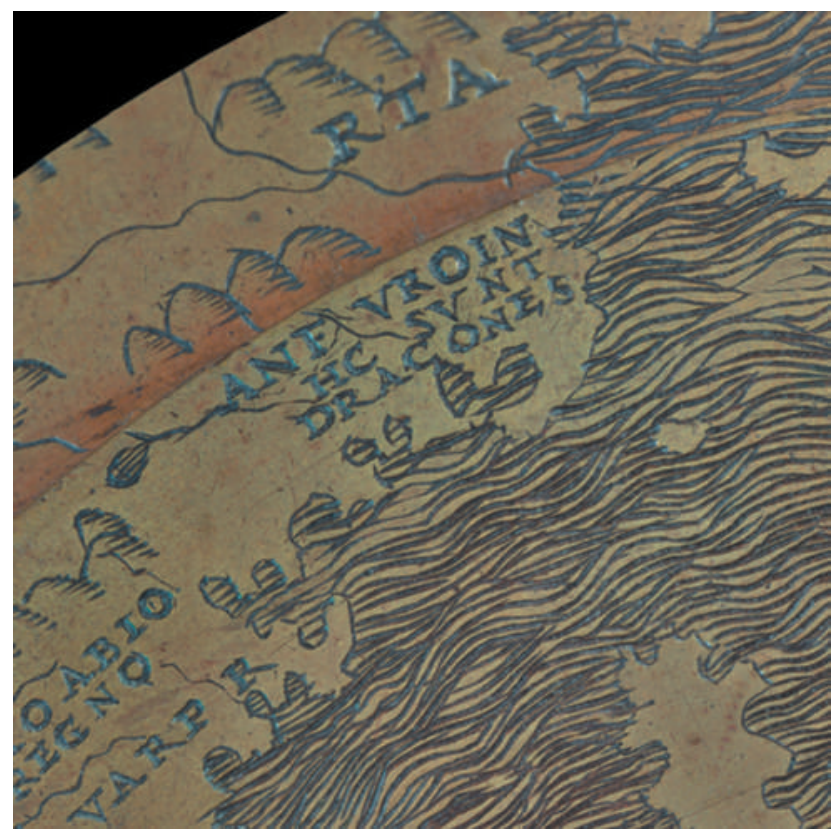

Figure 2: Hunt-Lenox Globe, Southern Hemisphere Detail: HC SVNT DRACONES New York Public Library, Public Domain. 
monsters, dragons or otherwise, as well as other dangerous creatures may often be associated with the edges of the known world, the term's reputation far outstrips the reality of its attestations, a thread that winds its way through constructions of space in the ancient world as well. ${ }^{6}$ In a similar vein, we may see two layers of preconceptions in the creation of distant places and spaces in the ancient world. The first centers on the existing perspectives that shaped how the societies of the ancient world viewed the lands around their own, be they real or imagined. The second, however, concerns our modern perspective on that same process of constructing and imagining space, which, as our surprisingly elusive dragons prove, is not without its own preconceptions.

Although they are all centered on the general question of the construction and manipulation of space and distance, the papers in this volume cover a range of topics that center on both core and peripheral regions of the ancient Near East and Mediterranean, as well as addressing the very concepts of core and periphery. Paul Delnero addresses the representations of space in Mesopotamia through an analysis of the Babylonian Map of the World, inarguably the most famous physical map from the cuneiform context. N. Ilgi Gerçek and Nancy Highcock focus on Anatolia, addressing descriptions of space in the Hittite empire and the border crossing abilities of the merchants of the Old Assyrian period, respectively. Seth Richardson and Michael Seymour both consider the nature of space within the context of the Neo-Assyrian empire, though through different analytical perspectives: Richardson examines the concept of perceiving distance through the medium and metaphor of hearing, while Seymour approaches depictions of Babylonia and markers of distant space through Assyrian palace reliefs. Stephen R. Russell considers the themes of crossing borders within Biblical texts and in reference to the territory of Israel, while Jennifer Finn examines the place of a geographic navel (or omphalos) in the Graeco-Roman world. The papers that focus on Mesopotamia and Anatolia provide a view on how distant lands and concepts such as border-crossing and world-building could be understood in various ways within the ancient Near East, while the remaining papers consider the related yet distinct ways in which this functioned in the broader ancient world. As a whole, this diverse, yet connected, group of papers aims to provide a similarly broad look at the representation of distant lands in the ancient world, a topic that encourages, if not requires, the application of a similarly broad range of analytical approaches.

6 Van Duzer (2012: 390-91) outlines the tendency for quite real but dangerous animals, such as lions, to also be located at the edges of medieval maps, while the theory of "climatic zones," espoused by a number of Graeco-Roman writers, positions the earth into a number of zones, by which places of geographic extremes are associated with similar climatic extremes and the natural home to monsters. See (Dicks 1955). 


\section{Border Studies and the Ancient World}

When we consider the broader topic of maps and map-making in the ancient world, it is Greece and Rome, not Mesopotamia, on which most scholarship centers. The Classical world has a wealth of both ancient writers discussing geography and modern scholars discussing those same sources in turn. Beyond travel narratives as observed in Herodotus, among others, the military campaigns of the Graeco-Roman rulers and conquerors benefit from more attention paid to the peculiarities that arise at the edges of their campaigns. ${ }^{7}$ I will not attempt a full - or even partial - recounting of the scholarship centered on geography during this period, and most works center on the Classical world to the exclusion of the ancient Near East. ${ }^{8}$ Cartographic studies continue well past antiquity, with investigations in particular into medieval mappaemundi, such as the Hereford world map. ${ }^{9}$ The social ramifications of cartography have been well-explored in more modern contexts, with an ever-increasing number of studies devoted to the post-colonial deconstruction of past and present maps, and to a consideration of how future maps might be created. ${ }^{10}$ Moving beyond cartography, the subjects of space, place, and landscape have been the focus of intense and dedicated study in archaeology and anthropology, with attention paid to how human societies define and are defined by the spaces they inhabit. ${ }^{11}$

7 The travels of Alexander, particularly in the east, acquired their own mythicized status in works such as the Romance of Alexander, a collection of legends surrounding his travels; (Stoneman 1991).

8 Given the wealth of sources concerning geography and empire in the Graeco-Roman world, that they center only on the Classical world is hardly surprising. Concerning more recent scholarship, see: (Bianchetti et al. 2015; Podossinov 2014), which includes a helpful overview on the problem of mapping in the Classical world (Arnaud 2014). The body of scholarship directly concerned with the Roman frontier is both ancillary to the immediate concerns of this essay and approached far more adroitly in Jennifer Finn's contribution. Furthermore, as the 2018 meeting of the Congress of Roman Frontier Studies (Limes) is its 24th iteration, it is a body of scholarship far too large to address here, by several orders of magnitude.

9 For an introduction to geographical constructions and mappaemundi in this period, see the edited volumes: (Tomasch and Gilles 1998; Harvey 2006).

10 In brief, see (Monmonier 2004; Jacob 2006), as well as an overview in (Woodward 1987).

11 See, as an introduction to such works; (Anchuetz, Wilshusen and Scheick 2001) and cited works; (Mitchell 2002; David and Thomas 2008). Though archaeological and anthropological works on space and place reach beyond the scope of this volume, they provide an important additional perspective to its studies, as can be seen in their more integrated use in Nancy Highcock's contribution. 
While Mesopotamia in particular has received less direct scholarly attention, several edited volumes that center on the Classical world also include studies on the ancient Near East, while works concerned with the Achaemenid period and later have considered the influence of the remnants of Mesopotamian civilizations on Graeco-Roman perspectives. ${ }^{12}$ The majority of scholarship that discusses space in the ancient Near East does so through the lens of frontier studies or targeted investigations into the empires or emerging polities of the ancient Near East, primarily during the second and first millennia BC. Works concerned with the emergence of polities on the periphery of Mesopotamia, such as Mitanni, have by necessity considered the role of borders and frontiers (Cancik-Kirshbaum et al 2014). Unsurprisingly, the majority of works on the frontier in the ancient Near East have centered on the actions of the NeoAssyrian empire, with attention also paid to the frontier in the Middle Assyrian period which preceded it. ${ }^{13}$ Scholars focused on the Neo-Assyrian period have studied both the mechanics of the empire as a whole (Liverani 2017) as well as its frontiers, utilizing both textual and archaeological evidence. ${ }^{14}$

Beyond these more imperially-centered works, focus in Mesopotamia has fallen on both the celestial and the terrestrial realms. In regards to the former, a number of works have analyzed the geography of the universe, particularly the arrangement of the heavens and earths within the greater organizational scheme of the universe as a whole (Horowitz 2011). The more terrestrially-oriented scholarship has centered on either the cuneiform texts to feature drawn maps (Millard 1987; Wheat 2013), or the genre of topographical texts, collected and

12 See (Rollinger 2016; Barker et al. 2015; Kristiansen et al. 1987) consider both Classical and ancient Near Eastern material, with the later emphasizing the Mesopotamian context. An edited volume by Raaflaub and Talbert (2009) considers the issue of perceptions of the world from a more global perspective, as indicated by their inclusion of papers concerning the ancient Near East (Michalowski 2009), the Classical World, India, China, and Mesoamerica, among other locations.

13 I reference here recent works by Jaume Llop, including those centered on the development of province territories in the Middle Assyrian period; see (Llop 2011: 591-93) for an overview on previous studies concerning the Assyrian provinces; an overview continued in a later article by Llop (2012), with its own associated bibliography. Llop and Daisuke Shibata (2016) also present an interesting analysis of the patterns of travel and verbs of motion that characterize the journeys of the king in this period.

14 A number of scholars have focused on the Neo-Assyrian empire and its hinterlands, including Bradley Parker, who examined the northern frontier of the empire in particular (Parker 2001). Parker also examined the concept of borders and frontiers from more anthropological (Parker 2006) and theoretical (Rodseth and Parker 2005) perspectives, while Ataç (2013) and Harmanşah (2012) both consider the nature and role of monuments as well as the landscape itself in the Assyrian empire and its borders. 
edited by Andrew George (1992). ${ }^{15}$ Other works have addressed these distant places, particularly those located in the Persian Gulf or Indus Valley, through the study of archaeological evidence as well as trading networks. ${ }^{16}$ As a more general summation of the studies on these themes, the Venice meeting of the Rencontre Assyriologique Internationale focused primarily on the theme of geography in all its contexts, with the title of Landscapes: Territories, Frontiers, and Horizons in the Ancient Near East. ${ }^{17}$ A number of other works, several of which will be discussed later, are concerned with distant locations as their own entities, considered and studied as places in their own right. In doing so, they provide an essential basis for comparing the reality of these distant spaces with Mesopotamia's own, often far more fantastical, conception of them. ${ }^{18}$

\section{At the Edges of the Map in the Ancient World}

Although the context of mental cartography of the Classical world and its writers differs considerably from the ancient Near East, we see the same general trend between the two; namely, that the further away one travels from the center, the more fantastical and wondrous, if dangerous, the locations become. In the Classical world, those edges shifted, but were most often located at the Pillars of Heracles, or the Straits of Gibraltar. ${ }^{19}$ Traveling beyond this point not only invites potential disaster, but forces one to interact with

15 Other works have expanded on these threads to analyze more distant aspects of Mesopotamian geography, centering on the role of more liminal spaces and the beings that inhabit them (Wiggermann 1996) or on the construction and significance of the horizon in literary texts (Woods 2009).

16 In recent works, see (Laursen and Steinkeller 2017). When considering the Indus valley, we see studies from scholars specializing in the cultures found at either end of the trading network; see (Ratnagar 2006).

17 The proceedings of the Venice meeting were subsequently collected in three edited volumes (Milano et al. 1999), covering topics that range from more concrete frontiers and their role in empires, to constructions of space in Mesopotamian art and more mental or imagined maps, which may have religious or mythological significance.

18 The interplay - as well as outright tension and conflict - between the imagined construction of distant lands and the reality of those same spaces remains a constant thread throughout the broad chronological spectrum of texts concerning the explorations (real or fictional) of distant lands; see (Dathorne 1994; Mittman 2006: 9-60).

19 The concept of distant lands in Greek and Roman texts has been explored at length by James Romm, considering the various sources that describe and explore these places. Romm describes how the Greek lyric poet Pindar (5th c. BC) places the Straits of Heracles as the pinnacle of human skill and daring; see (Romm 1992: 17). 
increasingly otherworldly spaces. ${ }^{20}$ However, the Greek world in particular also introduces a space beyond the fantastic - places which are characterized not by their wondrous qualities but only by their absence of all qualities. Described best in Herodotus, who otherwise details a more bounded map, these locations are found in each direction, and are described as "desolate"

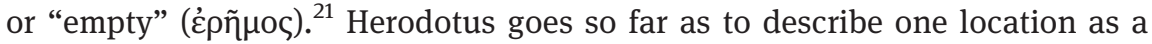

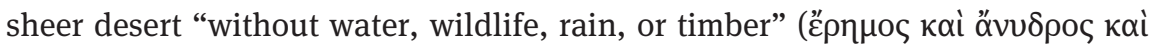

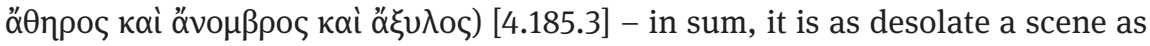
one could create. Herodotus leans on native sources to inform his more fantastical depictions of the inhabited edges of the map (Romm 1989: 12124), in part to distance himself from the responsibility of whether such descriptions are, in fact, true. However, the desolate and uninhabited nature of the most distant locations undermines such tactics. If there is no one who could conceivably report on these distant locations, it appears that they may as well have not existed at all.

Lacking both travel texts, and, more often than not, the aid of such native informants Herodotus invokes, we might ask how we could even begin to construct the edges of map - and beyond - in Mesopotamia? If we hope to find a concrete map, drawn as a fixed and somewhat immutable image, we have some time to wait, relative to the long span of roughly three-thousand years of Mesopotamian history. It is only circa $700 \mathrm{BC}$ that we see the first "map" of Mesopotamia, the Babylonian Map of the World (BM 92687). ${ }^{22}$ The map drawn on this tablet, as well as the description in the cuneiform text on its obverse and reverse, depict a more mythological conception of the world, with

20 A Greek manuscript, Periplous of Hanno, describes the journeys of its eponymous Carthaginian explorer (c. 6th-5th c. BC), who travels with his crew past the Pillars of Heracles and moves along the western coast of Africa. As he sails along the coast, he and his crew encounter a number of curious events whenever they make landfall, including the spectral sound of pipes and music. The crew are seized by fear and advised to flee back to their ship, they eventually threaten their captain with mutiny unless they cease their journey and return home; see (Carpenter 1966: 81-100).

21 These locations are considered in greater detail in (Romm 1992: 35-36). In the Histories, they appear in the following sections: 3.98.2; 4.17.2; 4.185.1-3; and 5.9.1. All referenced excerpts from the Histories follow published edition in (Waterfield 2008).

22 See (Horowitz 1988: 153), who cites that the map can be "no older than the ninth century," though it is often pinned to a later date; the British Museum's listing for the object cites a date of c. sixth century BC. Perhaps, unsurprisingly, given the theme of the papers in this volume, the Babylonian Map of the World makes several appearances, particularly as a focal point of Paul Delnero's article. 
recognizable terrestrial locations bounded by an encircling salt sea (marratu). ${ }^{23}$ Although we see a number of field plans and city maps on cuneiform tablets from earlier periods, this remains our earliest, and only, world map from Mesopotamia. ${ }^{24}$

Textual sources, however, provide a number of perspectives on the edges of the earth. One example, a first millennium BC literary text known as the Sargon Geography, provides an interesting construction of space: though Neo-Assyrian in origin, the text recounts the space conquered by Sargon of Akkad, who ruled in the twenty-fourth and twenty-third centuries BC. The text lists location after location, bringing each place under the dominion of the ruler and the reach of his reconstructed empire. ${ }^{25}$ While the Neo-Assyrian empire often invoked the image of the Sargonic rulers - and quite prominently, as seen in the very name of Sargon II (r. 722-705 BC) - the text creates a map that is distant in regards to its chronology as well as its geography. Though this text tracks a number of places positioned at the edge of the actual Neo-Assyrian empire, it also lists several locations that lie well beyond them. The text provides the distance to a number of locations, in travel time measured in double-hours (DANNA). This quite literal enumeration of distances begins with one of its farthest points, where 120 double-hours reaches from the center to "the border of the land Meluhha and Magan," here set as a distant point for the "totality of the land under the heavens" that Sargon conquered. ${ }^{26}$ In invoking these locations, the text positions them as a series of the most remote places that were nevertheless still seen as fully realized locations.

This relatively late piece connects the expansive glory of Sargon's empire to those of first millennium Mesopotamia, by engaging in a sort of chronological myth-making, if only arguably for an elite audience. It creates a sense of place, a mental topography distant in time as well as space. In doing so, it sets itself within a longer history and tradition of invoking distant places, locations which, though real, acquired fantastical qualities as a result of their distance from the Mesopotamian center. From the Ur III and Old Babylonian periods, those locations included the lands of Magan, in Oman; Marhashi, on the Iranian plateau to the east of Elam; Meluhha, in the Indus valley; Dilmun, located in the Persian

23 As discussed by (Horowitz 1988: 156). The sea continues to play a role as a boundary marker and division of known and unknown space, as evidenced by its use as such into the Roman period and well beyond; (Evans 2005).

24 For a fuller accounting of these tablets, see (Wheat 2013: 263-75).

25 The original edition of the Neo-Assyrian text is found in (Weidner 1952-53); for an updated edition, accounting for later, Neo-Babylonian copies, see (Grayson 1974-77; Horowitz 2011: 6795; Liverani 1999-2001).

26 Obverse 30-32, following edition in (Horowitz 2011: 67-95). 
Gulf as the island of Bahrain; and the Cedar Forest, located both to the east and, later and more predominantly, in the west, where it was associated with the cedar forests found in the mountains of Lebanon, as well as the Amanus mountains. ${ }^{27}$ Another location, the land of Aratta, was found only in literary texts, principally four Sumerian compositions concerning the figures Enmerkar and Lugalbanda, respectively (Vanstiphout 2003). Unlike the other locations cited above, which were not only represented in literary texts but also had entrenched connections with Mesopotamia through trade and military conquest, Aratta remains a fictional creation, finding its parallel in a wide number of other constructed fictional lands, such as the Kingdom of Prester John, or Lemuria. ${ }^{28}$

The concept of distance itself is expressed in a number of ways, particularly in earlier textual sources. In Sumerian, we see the phrase "distant land" (ki bad$\mathbf{r a}_{\mathbf{2}}$ ) found in a number of texts from the Old Babylonian period (c. 1800 BC) onwards, appearing in both literary texts and incantations. While it may simply be a reference to the near-unreachable distance associated with a particular location, other texts attribute more fantastical qualities to the locations it is used to describe. ${ }^{29}$ In the group of Sumerian exorcism incantations, forerunners to the later Udug Hul series, the term is used for one of the locations to which demons are expelled: "Go out, evil udug-demon, to a distant place (ki bad-ra $\mathbf{2}_{2}-\check{\mathbf{s}}_{3}$ ), go out, evil ala-demon, to the desert (a-ri-a-še $\mathbf{3}_{\mathbf{3}}$." ${ }^{\text {"30 }}$ Here, clearly, the desert is presented as a place as equally distant as any other possible location, and a safe terminal location to which the demon can be expelled, far from any human habitation. The term's most prosaic use is in another literary text, an elegy where the son of the recently deceased has "gone to the distant place"

27 Concerning early evidence for contact between Mesopotamia and locations in both the Persian Gulf and the Indus valley, see overview in (Potts 2016) and more extended discussion in (Laursen and Steinkeller 2017).

28 An overview of Aratta's hypothesized and even occasionally proposed locations may be found in (Potts 2004; Michalowski 1986). Regardless, the location only appears within literary texts and royal inscriptions, and its role within the four connected Sumerian epics to feature it most prominently is undoubtedly intended to be a fictional one. Both the Kingdom of Prester John and Lemuria have political as well as literary and historical ramifications that make them interesting points of comparison to Aratta; see (Brewer 2015) and (Ramaswamy 2004) for respective studies of the two lands.

29 See Curse of Agade, line 21; following edition in (Cooper 1983). Present in the Old Babylonian recension of the text, the phrase is employed to describe the land of Marhashi.

30 The Udug Hul (literally, "Evil Demons") incantation series is a sixteen-tablet series dedicated to expelling a number of supernatural threats. Though the forerunners are in monolingual Sumerian, the later series is primarily presented as a bilingual Akkadian-Sumerian text. For the quoted passage above, see Forerunners to Udug Hul, Tablet VIII: 7; following the edition in (Geller 1985). 
(ki bad-ra 2 gen). ${ }^{31}$ Unlike the previous references, this is clearly a place that, though distant, is one from which he can return, a journey he completes in order to mourn his father. In this sense we see the term take on multiple potential meanings: while several of its references clearly intend it to be a place inescapably distant, it may also be used to refer to a location that, while far away, is real enough to return from.

Travel appears as a trope in other literary texts from the Old Babylonian period, with emphasis placed on the ways in which distance is described, particularly over long journeys or when one moves outside of the borders of Mesopotamia, travelling to a distant land. Principally, a transition between spaces or the completion of a journey is delineated and clearly marked, often by an interval of seven. In the case of the Sumerian text Gilgamesh and Huwawa $A$, for example, which centers on Gilgamesh journey to the Cedar Forest to fight Huwawa, its monstrous guardian, it is only after Gilgamesh has crossed the seventh in a succession of mountain ranges that he encounters the cedar forest. We see the full iteration of Gilgamesh crossing mountain ranges one through six, before he reaches the seventh and finds the cedar forest (hur-sag imin-kam-ma bal-e-da-bi giš-eren ša 3 -ga-ni mu-ni-in-pad ). $^{32}$

Another remarkable description of distance and journeying appears in two literary texts centered around Lugalbanda, also from the Old Babylonian period. In the second of a connected duology of texts, Lugalbanda is lost in the wilderness on the way from Uruk to Aratta, stranded in the "farthest highlands" (kur ki $\left.\mathbf{s u}_{3}-\mathbf{r a}_{\mathbf{2}}\right)^{33}$ Having already encountered a number of wondrous sights and unearthly visions, he travels even further, to the "highland that knows no cypress" (ha-šu-ur ${ }_{\mathbf{2}}$ nu-zu kur-ra-ka). ${ }^{34}$ It is only here that he is able to reach the nest of the Anzu bird, a creature that grants him supernatural speed. Even with this boon, which allows him to travel great distances almost instantly, the space he covers must still be commented upon and his trip is described accordingly: Lugalbanda travels from the foot of the highlands (kur ur $\mathbf{u r}_{2}$-ra) through the mountains themselves, finally crossing over seven mountain ranges (hursag imin im-me-re-bal-bal) before reaching his destination. ${ }^{35}$ Beyond this, however, the narrative reveals the complicated relationship distant spaces may have to one another. Though the topography of these texts is fluid, Lugalbanda's

31 Seen in the Elegy on the Death of Nannaya, following edition in (Kramer 1960), with later additions in (Sjöberg 1983).

32 Gilgamesh and Huwawa A: 55. Transliteration following (Delnero 2006).

33 The Return of Lugalbanda: 1. Following edition in (Vanstiphout 2003: 136-37).

34 The Return of Lugalbanda: 36; (Vanstiphout 2003: 138-39).

35 The Return of Lugalbanda: 342-44; (Vanstiphout 2003: 154-55). 
adventures all take place in a journey between the familiar city of Uruk to the constructed but fully grounded location of Aratta. Within this wilderness, however, he travels to an even stranger space in order to reach the Anzu, before arriving at the less fantastical, if fictional, land of Aratta. Though the Anzu's nest may be spatially closer to Uruk than Aratta, it is a grander location, fantastical and ultimately liminal, and the relationship between these spaces, or between the foreign and the familiar, is thus not necessarily a linear one.

Regarding the lands themselves, we see that references to these various distant spaces may be found across a wide variety of texts, but most useful are undoubtedly the texts that list a number of such locations together, demarcating the edges of the known or imagined world. The Curse of Agade is one such text, describing how people from of the lands of Martu, Meluhha, Elam, and Subir all bring tribute to the city of Agade. Here, these locations are used to establish the lofty dominion of Agade - a height from which it will soon fall. Another Old Babylonian Sumerian literary text, Enki and Ninhursag, also includes a list of distant places. The text, which primarily concerns the exploits of its two titular deities, utilizes the location of Dilmun as its setting. Despite extensive documentation in the late third and early second millennium BC that places Dilmun as the hub of an extensive trading network in the Persian Gulf and beyond, the text assigns paradisiacal qualities to the location, positioning it as a proto-place, set before the more stable and ordered time that governs historical events. ${ }^{36}$ The Dilmun of Enki and Ninhursag exists in a space removed temporally as well as geographically. The list of foreign locations is used, similarly to their role within the Curse of Agade, to demarcate the edges of Dilmun's dominion.

The following lines are very much an outlier from the main text: while the majority of tablets are from the city of Nippur, these lines come instead from a tablet found at the city of Ur. Given the divergent nature of this section, it does appear to be a variant specific to this particular location. It shares with the other exemplars the lines that precede it, which establish the land of Dilmun as the "harbor warehouse of the homeland," (dilmun ${ }^{\mathbf{k i}} \mathbf{e}_{\mathbf{2}}$-gun $\mathbf{2}$ kar-ra kalam-ma-ka na-nam), thus emphasizing its role as a trading center and nexus for maritime trade through the Persian Gulf. The text from Ur, however, diverges by inserting a listing of a large number of foreign lands, all of which dedicate their particular and most iconic wealth to the land; arguably, the land of Dilmun itself. ${ }^{37}$ The

36 Letters referencing merchant traders from Dilmun, the alik Tilmun, attest to the prevalence of this trading route. One merchant in particular, Ea-Nāșir, acquires a certain notoriety in one letter from found at Ur because of his unscrupulous practices regarding the trade of copper; (see Oppenheim 1954; Potts 2006: 126-27).

37 The text of Enki and Ninhusag is edited in (Attinger 1984). 
text describes how the land of Tukriš will bring gold from the land of Harali; and how other distant lands will bring key, valuable items as tribute: from Meluhha, carnelian; from Magan, meš and $a b b a$ wood, along with copper, diorite and other stones; from Marhashi, precious stones and topaz; from the Sealand, ebony wood; and from the 'Tent'-lands and Elam both, wool. ${ }^{38}$ The text addresses Dilmun directly, stating how each of these lands will present its tribute (hu-mu-ra-ab-bal-bal-e). At the close of this section, the text proclaims that for Dilmun, Ur will load ships with sesame and fine cloth, and even the wide sea (a-ab-ba dagal-la) shall give Dilmun its riches (he $\left.\mathbf{2}_{\mathbf{2}}-\mathbf{g a l}_{\mathbf{2}} \mathbf{- b i}\right)$.

While this text may offer a useful listing of these distant lands, a helpful catalogue of key exports with which they were associated, it serves another purpose; namely, it highlights the subtle and often political ways in which these distant spaces could be employed. Although the text situates itself in Dilmun, and opens its narrative with a praise of that same location, the true focus of this long inserted passage is on the city of Ur, and it is perhaps no coincidence the passage is only found on a tablet from that location. The southern city was a prominent harbor and major port city, one of the Mesopotamian connections to trade through the Gulf. The text presents a number of lands: Tukriš and Harali were both positioned in the east (though neither is concretely identified), as was the overland location of Elam. But the focus is clearly fixed on maritime trade, with references to the mechanics of shipping in the opening and closing lines of this passage and multiple and quite specific references to the bounty that comes from such a trade, as well as a listing of goods associated with lands linked to Mesopotamia via maritime routes. It furthermore closes with a reference to the city Ur itself, and the great ships of the harbor city. Though the list of lands may inscribe a circle that purports to focus on Dilmun, its true center is Ur.

\section{Conclusion}

This is, of course, only a brief look at constructions of distance, and through the lens of several very particular examples. Despite that narrow focus, these texts still manage to reinforce one of the core principles espoused by the quoted section by Baudrillard discussed at the beginning of this essay. Namely, the created conceptions and ideas about distant lands holds as much weight, if not more, as the reality of those same spaces. The mental maps created by the peoples of the ancient world are inherently messy, and the ways in which they

38 This section appears as Text B, Col. II: 1-21 in (Attinger 1984: 12). The ETCSL online edition of Enki and Ninhusag lists these variant lines as 49A-49R. 
thought and conceived of the world they lived in, including the lands at and beyond its outermost edges, did not necessarily follow linear trajectories. During a journey from the familiar to the foreign, a "more distant" location may appear, hosting even more fantastical settings and creatures. It is clear that distance, and the idea of othering what is found at its edges, exists on both large and small scales.

Gilgamesh famously proclaims in his eponymous epic his desire to go and find Utanapishtim, the "Far-Away" ( $r \bar{q} q$ ), and proceeds to embark on a journey that demonstrates, to a degree, how broad an expanse of both space and time such a term could be expected to cover. As he approaches the edges of his own story's map, both the setting and creatures he encounters allow for a grander narrative: the literary conceptions of distant space also allowed for the application of a fantastical veneer to what might otherwise have been more ordinary space. Some of these locations, such as the Cedar Forest, cast as a foreign court with the monstrous Huwawa as its sovereign, cannot escape political echoes and entanglements, but the fantastical nature of other spaces seems engineered to serve the narrative. While there is clearly a political dimension to many of these distant locations - found in their very existence, their descriptions and representations within texts, the specific ways in which they were invoked and their relationship to each other - it would be unnecessarily reductive to equate all distant spaces with neat political allegories for military power or the reach of a king's rule. These locations are representative of a more complicated world view, where creating as well as crossing borders were inherently interstitial acts, engaging with the liminal nature of these locations while also subverting their own definition as the "Far-Away."

Acknowledgements: My thanks for Emily Cole, Sebastian Fink, and Shana Zaia for their comments on earlier drafts of this article.

\section{References}

Anschuetz, K.F., R. Wilshusen, and C.L. Scheick. 2001. An Archaeology of Landscapes:

Perspectives and Directions. Journal of Archaeological Research 9: 157-211.

Arnauld, P. 2014. Mapping the Edges of the Earth: Approaches and Cartographical Problems.

Pp. 31-59 in The Periphery of the Classical World in Ancient Geography and Cartography, ed. A.V. Podossinov. Leuven: Peeters.

Ataç, M.-A. 2013. "Imaginal" Landscapes in Assyrian Imperial Monuments. Pp. 383-423 in Experiencing Power: Generating Authority: Cosmos, Politics, and the Ideology of Kingship in Ancient Egypt and Mesopotamia, ed. J.A. Hill, P. Jones and A.J. Morales. Philadelphia: University of Pennsylvania Press. 
Attinger, P. 1984. Enki Et Nin[h]urs[g]a. ZA 74: 1-52.

Barker, E., S. Bouzarovski, C. Pelling, and L. Isaksen (Eds.) 2015. New Worlds from Old Texts: Revisiting Ancient Space and Place. Oxford: Oxford University Press.

Baudrillard, J. 1994. Simulacra and Simulation, trans. Sheila Glaser. Ann Arbor: University of Michigan Press.

Bianchetti, S., M. Cataudella, and H.J. Gehrke (Eds.) 2015. Brill's Companion to Ancient Geography: The Inhabited World in Greek and Roman Tradition. Leiden: Brill.

Borges, J.L. 1999. On the Exactitude of Science. Pp. 325 in Jorge Luis Borges: Collected Fictions, trans. H. Hurley. New York: Penguin Books.

Brewer, K. 2015. Prester John: The Legend and Its Sources. New York: Routledge.

Cancik-Kirschbaum, E., N. Brisch, and J. Eidem (Eds.) 2014. Constituent, Confederate, and Conquered Space: The Emergence of the Mittani State, Topoi - Berlin Studies of the Ancient World 17. Berlin: de Gruyter.

Carpenter, R. 1966. Beyond the Pillars of Heracles: The Classical World Seen through the Eyes of Its Discoverers. London: Delacorte Press.

Cooper, J.S. 1983. The Curse of Agade. Baltimore: John Hopkins University Press.

Dathorne, O.R. 1994. Imagining the World: Mythical Belief versus Reality in Global Encounters. Westport: Bergin and Garvey.

David, B. and J. Thomas (Eds.) 2008. Handbook of Landscape Archaeology. Walnut Creek, CA: Left Coast Press.

Delnero, P. 2006. Variation in Sumerian Literary Compositions: A Case Study Based on the Decad (Doctoral Dissertation). Philadelphia: University of Pennsylvania.

Dicks, D.R. 1955. The Klimata in Greek Geography. The Classical Quarterly 2: 248-255.

Evans, R. 2005. The Cruel Sea? Ocean as Boundary Marker and Transgressor in Pliny's Roman Geography. Antichthon 39: 105-119.

Gardiner, M.Q. and S. Engler. 2010. Charting the Map Metaphor in Theories of Religion. Religion 40: 1-13.

Geller, M.J. 1985. Forerunners to Udug-Hul: Sumerian Exorcistic Incantations. Freiburger altorientalische Studien 12. Stuttgart: Franz Steiner Verlag GmbH.

George, A.R. 1992. Babylonian Topographical Texts. Orientalia Lovaniensia Analecta 40. Leiden: Peeters Publishing.

Gilbert, J. 1728. An Abstract of the Essay of Human Understanding. The Present State of the Republick of Letters 1: 373-394.

Grayson, A.K. 1974-77. The Empire of Sargon of Akkad. AfO 25: 56-64.

Harmanşah, Ö. 2012. Beyond Aššur: New Cities and the Assyrian Politics of Landscape. BASOR 365: 53-77.

Harvey, P.D.A. 2006. The Hereford World Map: Medieval World Maps and Their Context. London: the British Library.

Horowitz, W. 1988. The Babylonian Map of the World. Iraq 50: 147-165.

Horowitz, W. 2011. Mesopotamian Cosmic Geography. 2nd. Winona Lake: Eisenbrauns.

Jacob, C. 2006. The Sovereign Map: Theoretical Approaches in Cartography Throughout History, trans. Tom Conley. Chicago: University of Chicago Press.

Korzybski, A. 1994. Science and Sanity: An Introduction to Non-Aristotelian Systems and General Semantics. 5th. New York: Institute of General Semantics.

Kramer, S.N. 1960. Two Elegies on A Pushkin Museum Tablet: A New Sumerian Literary Genre. Moscow: Oriental Literature Publishing House. 
Kristiansen, K., M. Larsen, and M. Rowlands (Eds.) 1987. Centre and Periphery in the Ancient World. Cambridge: Cambridge University Press.

Laursen, S. and P. Steinkeller. 2017. Babylonia, the Gulf Region, and the Indus: Archaeological and Textual Evidence for Contact in the Third and Early Second Millennia BC. Mesopotamian Civilizations 21. Winona Lake: Eisenbrauns.

Liverani, M. 1999-2001. The Sargon Geography and the Late Assyrian Mensuration of the Earth. Pp. SAAB XII: 57-85.

Liverani, M. 2017. Assyria: The Imperial Mission. Mesopotamian Civilizations 20. Winona Lake: Eisenbrauns.

Llop, J. 2011. The Creation of the Middle Assyrian Provinces. JAOS 131: 591-603.

Llop, J. 2012. The Development of the Middle Assyrian Provinces. AoF 39: 87-111.

Llop, J. and D. Shibata. 2016. The Royal Journey in the Middle Assyrian Period. JCS 68: 67-98. Michalowski, P. 1986. Mental Maps and Ideology: Reflections of Subartu. Pp. 129-156 in The Origins of Cities in Dry-Farming Syria and Mesopotamia in the Third Millennium B.C., ed. H. Weiss. Guilford: Four Quarters.

Michalowski, P. 2009. Masters of the Four Corners of the Heavens: Views of the Universe in Early Mesopotamian Writings. Pp. 147-168 in Geography and Ethnography: Perceptions of the World in Pre-Modern Societies, ed. K.A. Raaflaub and R.J.A. Talbert. Oxford: WileyBlackwell.

Milano, L., S. De Martino, F.M. Fales, and G.B. Lanfranchi (Eds.) 1999. Landscapes: Territories, Frontiers, and Horizons in the Ancient near East. Papers Presented to the KLIV Rencontre Assyriologique Internationale, Venezia, 7-11 July 1997. Padova: Sargon srl.

Millard, A.R. 1987. Cartography in the Ancient near East. Pp. 107-116 in Cartography in Prehistoric, Ancient, and Medieval Europe and the Mediterranean: Volume One, ed. J.B. Harley and D. Woodward. Chicago: University of Chicago.

Mitchell, W.J.T. (Ed.) 2002. Landscape and Power. Chicago: University of Chicago Press. Mittman, A.S. 2006. Maps and Monsters in Medieval England. New York: Routledge.

Monmonier, M. 2004. Rhumb Lines and Map Wars: A Social History of the Mercator Projection. Chicago: University of Chicago Press.

Oppenheim, A.L. 1954. The Seafaring Merchants of Ur. JAOS 74: 6-17.

Parker, B.J. 2001. The Mechanics of Empire: The Northern Frontier of Assyria as a Case Study in Imperial Dynamics. Helsinki: University of Helsinki.

Parker, B.J. 2006. Toward an Understanding of Borderland Processes. American Antiquity 71: 77-100.

Podossinov, A.V. (Ed.) 2014. The Periphery of the Classical World in Ancient Geography and Cartography. Leuven: Peeters.

Pongratz-Leisten, B. 2001. Mental Map Und Weltbild in Mesopotamien. Pp. 261-279 in Das Biblische Weltbild Und Seine Altorientalischen Kontexte, ed. B. Janowski and B. Ego. Heidelberg: Mohr Siebeck.

Potts, D.T. 2004. Exit Aratta: Southeastern Iran and the Land of Marhashi. Nāme-Ye Irān-E Bāstān 1-11.

Potts, D.T. 2006. Babylonian Sources of Exotic Raw Materials. Pp. 124-140 in The Babylonian World, ed. G. Leick. New York: Routledge.

Potts, D.T. 2016. Cultural, Economic, and Political Relations between Mesopotamia, the Guild Regions, and India before Alexander. Pp. 109-118 in Megasthenes Und Seine Zeit, ed. J. Wiesehöfer, H. Brinkhaus and R. Bichler. Classica et Orientalia 13. Wiesbaden: Harrassowitz Verlag. 
Raaflaub, K.A. and R.J.A. Talbert (Eds.) 2009. Geography and Ethnography: Perceptions of the World in Pre-Modern Societies. Oxford: Wiley-Blackwell.

Ramaswamy, S. 2004. The Lost Land of Lemuria: Fabulous Geographies, Catastrophic Histories. Berkeley: University of California Press.

Ratnagar, S. 2006. Trading Encounters: From the Euphrates to the Indus in the Bronze Age. 2nd. Oxford: Oxford University Press.

Rodseth, L. and B. Parker. 2005. Theoretical Considerations in the Study of Frontiers. Pp. 3-21 in Untaming the Frontier in Anthropology, Archaeology and History, ed. B.J. Parker and L. Rodseth. Tucson: University of Arizona Press.

Rollinger, R. 2016. Megasthenes, Mental Maps and Seleucid Royal Ideology: The Western Fringes of the World or How Ancient near Eastern Empires Conceptualized World Domination. Pp. 129-164 in Megasthenes Und Seine Zeit, ed. J. Wiesehöfer, H. Brinkhaus and R. Bichler. Classica et Orientalia 13. Wiesbaden: Harrassowitz Verlag.

Romm, J. 1989. Belief and Other Worlds: Ktesias and the Founding of the "Indian Wonders.". Pp. 121-135 in Mindscapes: The Geographies of Imagined Worlds, ed. G.E. Slusser and E.S. Rabkin. Carbondale: Southern Illinois University Press.

Romm, J. 1992. The Edges of the Earth in Ancient Thought: Geography, Exploration, and Fiction. Princeton: Princeton University Press.

Scafi, A. 2006. Mapping Paradise: A History of Heaven on Earth. Chicago: University of Chicago Press.

Sjöberg, A.W. 1983. The First Pushkin Museum Elegy and New Texts. JAOS 103: 315-320. Smith:, J.Z. 1978. Map Is Not Territory: Studies in the History of Religions. Brill: Leiden. Stoneman, R. Trans. 1991. The Greek Alexander Romance. New York: Penguin.

Tomasch, S. and S. Gilles. 1998. Text and Territory: Geographical Imagination in the European Middle Ages. Philadelphia: University of Pennsylvania Press.

Van Duzer, C. 2012. Hic Sunt Dracones: The Geography and Cartography of Monsters. Pp. 387-435 in Ashgate Research Companion to Monsters and the Monstrous, ed. A.S. Mittman and P.J. Dendle. Aldershot: Ashgate.

Vanstiphout, H. 2003. Epics of the Sumerian Kings: The Matter of Aratta. Atlanta: Society of Biblical Literature, Writings from the Ancient World 20.

Waterford, R. trans. 2008. Herodotus, The Histories. Oxford: Oxford University Press.

Weidner, E. 1952-53. Dar Reich Sargons Von Akkad. AfO 16: 1-24.

Wheat, E. 2013. Terrestrial Cartography in Ancient Mesopotamia (Doctoral Dissertation). University of Birmingham.

Wiggermann, F. 1996. Scenes from the Shadow Side. Pp. 207-230 in Mesopotamian Poetic Language: Sumerian and Akkadian, ed. M.E. Vogelzang and H.L.J. Vanstiphout. Cuneiform Monographs 6. Groningen: Styx Publications.

Woods, C. 2009. At the Edge of the World - Cosmological Conceptions of the Eastern Horizon in Mesopotamia. JANER 9: 183-239.

Woodward, D. 1987. Medieval Mappaemundi. Pp. 286-370 in Cartography in Prehistoric, Ancient, and Medieval Europe and the Mediterranean: Volume One, ed. J.B. Harley and D. Woodward. Chicago: University of Chicago. 